\title{
Measuring Financial Performance Based on CAMEL: A Study on Selected Islamic Banks in Bangladesh
}

\author{
Mohammad Kamrul Ahsan \\ Senior Lecturer, Department of Business Administration, Metropolitan University, Sylhet, BANGLADESH \\ E-mail for correspondence: ahsan404243@gmail.com
}

\begin{abstract}
The aim of this paper is to analyze the financial performance of three selected Islamic Banks (Islami Bank Bangladesh Limited, Export Import Bank of Bangladesh Limited, Shahjalal Islami Bank Limited) over a period of eight years (2007-2014) in Bangladeshi banking sectors. For this reason, CAMEL Rating Analysis approach has been conducted and it is found that all the selected Islamic Banks are in strong position on their composite rating system. They are basically sound in every respect i.e., sound in capital adequacy, asset quality, management quality, earning capacity and liquidity conditions.
\end{abstract}

Keywords: CAMEL Rating Analysis, Islamic Banks

\section{INTRODUCTION}

The banking sectors are treated as the back-bone of an economy. In the same way, there are several types of banks (Conventional, Islamic, Specialized) in Bangladesh. Of these banks, Islamic banks are in growing position in our country. As the most of the people in our country are Muslims, they prefer to deposit and take loans from the Islamic banks in the sense of Islam. For this reason, the researcher tries to find out Islamic banks' performance in Bangladesh. To measure the performance, the researcher selects three Islamic banks randomly and chooses CAMEL Rating Analysis system. CAMEL stands for:

\begin{tabular}{|c|l|}
\hline Alphabet & Stands for \\
\hline C & Judgment of Capital Adequacy \\
\hline A & Judgment of Asset Quality \\
\hline M & Judgment of Efficiency and Quality of Management \\
\hline E & Judgment of the Volume and Level of Earnings \\
\hline L & Judgment of Strength and Level of Liquidity \\
\hline
\end{tabular}

Piyu (1992) notes "Currently, financial ratios are often used to measuring the overall financial soundness of a bank and the quality of its management. Bank regulators, for example, use financial ratios to help evaluate a bank's performance as part of the CAMEL system". The evaluation factors are as follows:

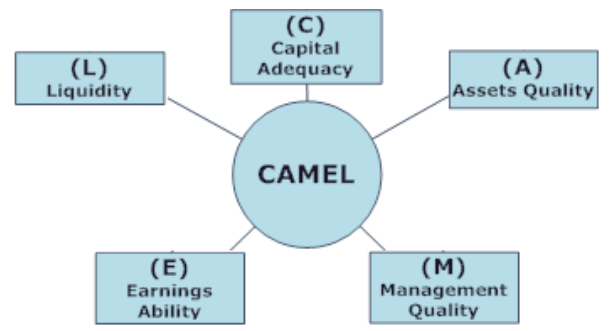

Figure 1: Meaning of CAMEL, Source: Piyu, 1992

\section{Components of CAMEL Rating System}

The dimension of capital adequacy is an important factor to help the bank in understanding the shock attractive capability during risk. In this study, capital adequacy is measured by using the equity to total assets ratio (Vong \& Chan, 2009). That means, capital adequacy enables a bank to meet any financial unexpected condition due to FX risk, credit risk, market risk, interest rate risk. Capital adequacy protects the interest of depositors of a bank.

The dimension of asset quality is an important factor to help the bank in understanding the risk on the exposure of the debtors. In this paper, this parameter is measured by the provision for loan loss \begin{tabular}{c|l} 
Asset & reserve to total asset ratio (Merchant, \\
Quality & 2012). This ratio assures to cover the bad
\end{tabular} and doubtful loans of the bank. This parameter will benefit the bank in understanding the amount of funds that have been reserved by the banks in the event of bad investments.

Management quality reflects the management soundness of a bank. The management acts as a safeguard to operate the bank in a smooth and decent manner and is called excellence management or skillful management, whenever it controls its cost and increases productivity, ultimately achieving higher profits. Here, this parameter is measured by total cost to total income ratio. 


\begin{tabular}{|c|c|}
\hline $\begin{array}{l}\text { Earnings } \\
\text { Quality }\end{array}$ & $\begin{array}{l}\text { Earning is an important parameter to } \\
\text { measure the financial performance of an } \\
\text { organization. Earning quality mainly } \\
\text { measures the profitability and productivity } \\
\text { of the bank, explains the growth and } \\
\text { sustainability of future earnings capacity. In } \\
\text { the same way, bank depends on its earning } \\
\text { to perform the activities like funding } \\
\text { dividends, maintaining adequate capital } \\
\text { levels, providing for opportunities for } \\
\text { investment for bank to grow, strategies for } \\
\text { engaging in new activities and maintaining } \\
\text { the competitive outlook. Here two ratios are } \\
\text { used to determining the profitability of } \\
\text { banks i.e., return on asset and return on } \\
\text { equity. }\end{array}$ \\
\hline $\begin{array}{c}\text { Liquidity } \\
\text { Performance }\end{array}$ & $\begin{array}{l}\text { Liquidity ratio in a bank measures the } \\
\text { ability to pay its current obligations } \\
\text { (Hazzi \& Kilani, 2013). For having sound } \\
\text { banking operations it needs to have } \\
\text { liquidity solvency. If any bank faces } \\
\text { liquidity crisis, bank can't meet up its } \\
\text { short-term obligations. Liquidity crisis } \\
\text { seems to be a curse to the image of banks. } \\
\text { So it is a prime concern to banks. Cash } \\
\text { and investments are the most liquid } \\
\text { assets of a bank. An adequate liquidity } \\
\text { position means a situation, where } \\
\text { institution can obtain sufficient funds, } \\
\text { either by rising liabilities or by converting } \\
\text { its assets quickly at a reasonable cost. } \\
\text { Here liquidity performance is measured } \\
\text { by net investment to total asset ratio. This } \\
\text { ratio can be defined as the amounts of } \\
\text { assets have been engaged in investment. }\end{array}$ \\
\hline
\end{tabular}

\section{OBJective}

The main objective of this research paper is to analyze the financial performance of selected Islamic Banks in Bangladesh based on CAMEL Rating Analysis.

\section{Methodology}

Basically, this study is descriptive, analytical and empirical in nature and executed using the published financial statements of banks.

\section{Sample Composition}

This study focuses on domestic Islamic banks. The population for this study is the all Islamic banks that operate inside Bangladesh. The sample size is comprised of 3 full-fledged Islamic banks. These 3 Islamic banks are selected randomly from 8 Islamic banks in Bangladesh. These selected banks are:

\begin{tabular}{|c|c|}
\hline Serial No. & Name of Banks \\
\hline 1 & Islami Bank Bangladesh Limited (IBBL) \\
\hline 2 & $\begin{array}{l}\text { Export Import Bank of Bangladesh Limited } \\
\text { (EXIM Bank) }\end{array}$ \\
\hline 3 & Shahjalal Islami Bank Limited (SJIBL) \\
\hline
\end{tabular}

\section{Data Sources}

This study is purely based on secondary data. The financial data of selected banks have been collected from the financial statements of the respected banks. The financial statements have been collected from the Official Websites of selected banks, i.e., 1. www.islamibankbd.com, 2. www.eximbankbd.com, 3. www.sjiblbd.com .

\section{Study Period}

An eight year period (2007-2014) has been selected for evaluating the financial performance of selected Islamic banks in Bangladesh.

\section{Data Analysis Tools}

This study covers the period of eight years from 20072014. To measure the financial performance of Islamic banks, CAMEL analysis is used, which is a standard analysis for measuring performance of financial institutions and the latest tool nowadays. CAMEL test consists of Capital Adequacy, Asset Quality, Management Quality, Earning Ability and Liquidity. To achieve the desired results, the researcher would like to utilize six ratios that define their respective parameters of CAMEL. These are mentioned in the following:

\begin{tabular}{|l|l|}
\hline \multicolumn{1}{|c|}{ CAMEL Parameters } & \multicolumn{1}{c|}{ Ratios } \\
\hline Capital Adequacy & Equity to Asset \\
\hline Asset Quality & Investment Loss Reserve \\
\hline Management Quality & Cost to Income \\
\hline Earning Performance & i) Net Profit to Total Asset \\
\hline & ii) Net Profit to Total Equity \\
\hline Liquidity & Net Loan to Total Asset \\
\hline
\end{tabular}

Source: Merchant, 2012

\section{Meaning of Composite Rating under CAMEL Rating Analysis}

There are five categories of composite CAMEL ratings. These are:

\begin{tabular}{|c|c|l|}
\hline Rating & Composite Range & Description \\
\hline 1 & $1.00-1.49$ & Strong \\
\hline 2 & $1.50-2.49$ & Satisfactory \\
\hline 3 & $2.50-3.49$ & Fair \\
\hline 4 & $3.50-4.49$ & Marginal \\
\hline 5 & $4.50-5.00$ & Unsatisfactory \\
\hline
\end{tabular}

Source: Khan, 2008

Meaning of composite rating under CAMEL Rating Analysis:

1. Composite Rating 1: (1.00-1.49) Strong

- Basically, sound in every respect.

- Findings are of a minor nature and can be handled routinely.

- Resistant to external economic and financial disturbances.

- No cause for supervisory concern. 
2. Composite Rating 3: (1.50-2.49) Satisfactory.

- Fundamentally sound.

- $\quad$ Findings are of a minor nature and can be handled routinely.

- $\quad$ Stable and can withstand business fluctuations well.

- Supervisory concerns are limited to the extent that findings are corrected.

3. Composite Rating 3: (2.50-3.49) Fair

- Financial, operational or compliance weakness ranging from moderately severe to unsatisfactory.

- Vulnerable to the onset of adverse business conditions.

- Easily deteriorate if actions are not effective in correcting weaknesses.

- Supervisory concern and more than normal supervision to address deficiencies.

4. Composite Rating 4: (3.50-4.49) Marginal

- The immoderate volume of serious financial weaknesses.

- Unsafe and unsound conditions may exist which are not being satisfactorily addressed.

- Without corrections, these conditions could develop further and impair future viability.

- High potential for failure.

- Close supervision surveillance and a definite plan for correcting deficiencies.

5. Composite Rating 5: (4.50-5.00) Unsatisfactory

- High immediate or near-term probability failure.

- The severity of weaknesses is so critical that urgent aid from stockholders or other financial sources in necessary.

- Without immediate corrective actions, will likely require liquidation, merger or acquisition. (Source: Khan, 2008)

\section{Interpretation of Different Ratings (by Trautmann, 2006)}

\begin{tabular}{|c|l|}
\hline Rating & \multicolumn{1}{|c|}{ Description } \\
\hline 1 & Indicates strong performance \\
\hline 2 & $\begin{array}{l}\text { Indicates above average performance which } \\
\text { means sound and relatively safe operations. }\end{array}$ \\
\hline 3 & $\begin{array}{l}\text { Indicates performance that is flawed to some } \\
\text { degree. }\end{array}$ \\
\hline 4 & $\begin{array}{l}\text { Indicates unsatisfactory performance. If left } \\
\text { unchecked, such performance could threaten } \\
\text { the solvency of the banking company. }\end{array}$ \\
\hline 5 & $\begin{array}{l}\text { Indicates very unsatisfactory performance, in } \\
\text { need of immediate remedial attention for the } \\
\text { sake of the banking company's survival. }\end{array}$ \\
\hline
\end{tabular}

Source: Trautmann, 2006

\section{LIMITATIONS}

The main limitation of this study is that data are insufficient considering that Official Websites have financial reports of limited years (2007-2014). This study is confined only to some selected Islamic banks, selected parameters and the study period is eight years only.

\section{LITERATURE REVIEW}

In the early 1970s, federal regulators in the USA developed the CAMEL rating system to help structure the bank examination process. In 1979, the Uniform Financial Institutions Rating System was adopted to provide federal bank regulatory agencies with a framework for rating financial condition and performance of individual banks (Siems \& Barr, 1998).

Barker \& Holdsworth (1993) predicted banks failure; they found evidence that CAMEL rating is useful, even after controlling a wide range of publicly available information about the condition and performance of banks. According to Deyoung et al. (2001) "The CAMELS focuses on the evaluation of the performance of the financial institutions by examining its balance sheet, as well as, profit and loss statement by each component, thus observing the institution's dynamic aspect".

Doumpos \& Zopounidis (2009) said that "In the new globalize financial system, as with all new financial markets and products, the banks' economic situation can rapidly change than in the past. As a result of the new situation, supervisory authorities were directed towards changing their way of approach and assessment, paying more importance on ways to overcome and manage risks". As a result, this new situation that was created through the development of the financial system, a further area of assessment was added indicating market risk.

Verma (2003) had studied the performance of the public sector banks based on CAMEL Model to judge its financial and operational conditions. However, the study a composite ratings are based on careful evaluation of an institutions operational, financial and compliance performance. Gupta \& Siabal (2007) used CAMEL Model for evaluating banking sector in India. The study concluded that Indian banks are strong considered to have the quality of assets and capital adequacy. Cole \& Gunther (1998) findings that CAMEL ratings contain useful information. However, Hirtle \& Lopez (1999) stress that the bank's CAMEL rating is highly confidential, and only exposed to the bank's senior management for the purpose of projecting the business strategies, and to appropriate supervisory staff. Its rating is never made publicly available, even on a lagged basis.

Barr et al. (2002) viewed that "CAMEL rating has become a concise and indispensable tool for examiners and regulators". This rating ensures a bank's healthy conditions by reviewing different aspects of a bank based on variety of information sources such as a financial statement, funding sources, macroeconomic data, budget and cash flow. Said \& Saucier (2003) examined the 
liquidity, solvency and efficiency of Japanese Banks using CAMEL rating methodology, for a representative sample of Japanese banks for the period 1993-1999, they evaluated capital adequacy, assets and management quality, earnings ability and liquidity position.

Godlewski (2003) tested the validity of the CAMEL rating typology for bank's default modification in emerging markets. He focused explicitly on using a logical model applied to a database of defaulted banks in emerging markets. Nurazi \& Evans (2005) investigated whether CAMEL ratios could be used to predict bank failure. The results suggested that adequacy ratio, assets quality, management, earnings, liquidity and bank size are statistically significant in explaining bank failure. Tarawneh (2006) investigated a comparison of financial performance of Omani's commercial banks using CAMEL model and he work on different measureable relationships between bank's size, asset management, operational efficiency and financial performance.

Najjar (2008) analyzed the Bank of Palestine and Jordan Ahli Bank. The main objectives of this study were to investigate into the performance of Jordan Ahli Bank and Palestine, and used the CAMEL analysis to ensure equitable distribution to shareholders depends on fundamental analysis. Wirnkar \& Tanko (2008) considered the banking performance of major Nigerian banks using the CAMEL framework. Ali (2009) has worked on a project on camels framework, investigated the strengths of using camels framework as a tool of performance evaluation for banking institutions of Kathmandu.

Dar \& Presley (2000) have discussed and analyzed the third area of CAMEL model i.e., Management and control of internal governance of banks and financial companies. The Islamic banks and financial companies of Muslim world are taken into consideration. They have found that the an absence of correct balance between management and control rights is the major cause of lack of profit and loss sharing in the Islamic finance structures. Like other developed countries, Bangladesh Bank introduced CAMEL Rating System in 1993 as an integral part of Offsite Supervision System (Iqbal, 2012). Kabir \& Dey (2012) examined the performance Private, Commercial of Bangladeshi banks by adopting the CAMEL Model. Nimalathasan (2008) highlighted comparison of financial performance of banking sector in Bangladesh using CAMELS rating system

Sarker (2005) examined the CAMEL model for regulation and supervision of Islamic banks by the central bank in Bangladesh. This study enabled the regulators and supervisors to get a Shariah benchmark to supervise and inspect Islamic banks and Islamic financial institutions from an Islamic perspective. Siems \& Barr (1998) explained each of the five factors is scored from one to five, with one being the strongest rating. An overall composite CAMEL rating also ranges from one to five. The Federal Reserve System in U.S. describes the five composite rating levels as follows-

\begin{tabular}{c|l} 
Rating & \multicolumn{1}{|c}{ Description } \\
\hline 1 & $\begin{array}{l}\text { An institution that is basically sound in every } \\
\text { respect. }\end{array}$ \\
\hline 2 & $\begin{array}{l}\text { An institution that is fundamentally sound but } \\
\text { has modest weaknesses. }\end{array}$ \\
\hline 3 & $\begin{array}{l}\text { An institution with financial, operational, or } \\
\text { compliance weaknesses that give cause for } \\
\text { supervisory concern. }\end{array}$ \\
\hline 4 & $\begin{array}{l}\text { An institution with serious financial } \\
\text { weaknesses that could impair future viability. }\end{array}$ \\
\hline 5 & $\begin{array}{l}\text { An institution with critical financial } \\
\text { weaknesses that render the probability. }\end{array}$
\end{tabular}

Due to the rapid development in Islamic banking in these recent years, it calls for opportunities for the academics to conduct the study in analyzing its' financial performance using CAMEL rating system. Some previous studies investigated the performance of Islamic banks during certain period (Sarker, 1999; Wibowo \& Saptutyningsih, 2004) while the others studied the performance of Islamic Banks and compared it with conventional banks performance (Samad, 1999; Samad and Hassan, 2000; Rosly and Bakar, 2003; Samad, 2004; Kader et. al, 2007; Widagdo and Ika; 2007). Samad (2004) examined on the financial performance of interest-free Islamic banking against interest-based conventional bank in Bahrain.

Akkas (1996) compared the efficiency of Islamic banking with conventional banking in Bangladesh. He found that the Islamic banks are relatively more efficient than conventional banks. Safiullah (2010) argued that financial performance (solvency and liquidity, business developments, profitability, efficiency and productivity, commitment to economy and community) of both streams of the banks is remarkable. He found that obligation to productivity and efficiency, community and economy, indicates that the interest-based conventional banks are doing much better performance than the interest-free Islamic banks. He also found that the performance of Interest-free Islamic banks in business development, liquidity, profitability and solvency is more superior to that of interest-based conventional banks. So he found that Islamic banks are considerably better in financial performance than the conventional banks.

Jaffar \& Manarvi (2011) assessed the performance of Islamic and conventional banks through CAMEL test during the period of 2005 to 2009. The sample of their research was five Islamic and five conventional banks. They found that Islamic banks performed better and had high liquidity than the conventional banks, besides it is understood that conventional banks have pioneered in the management and having a good earning ability. 


\section{AnALYSIS AND Findings}

\section{Capital Adequacy}

Table 1: Shareholder Equity to Total Assets (EQTA)

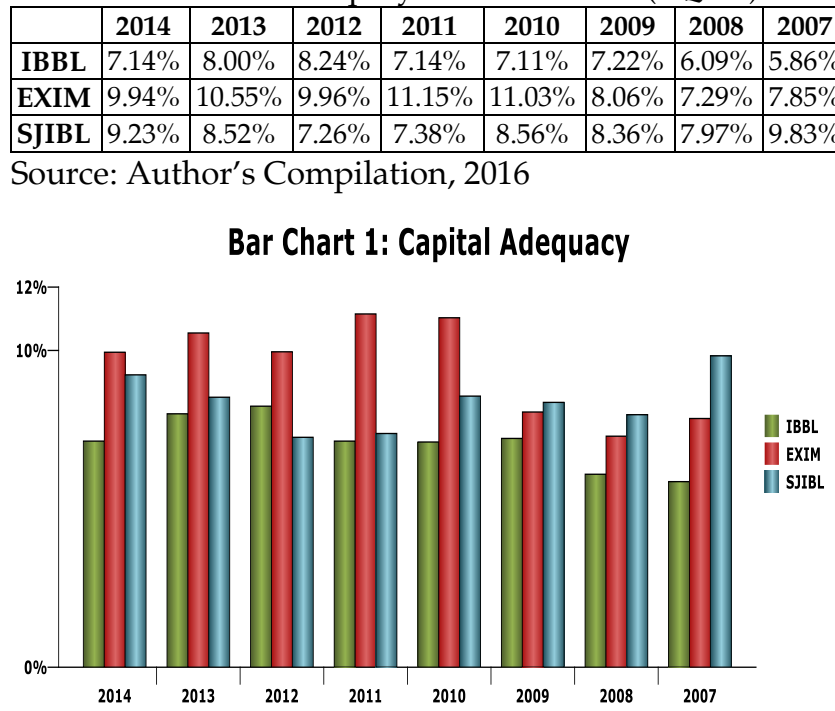

Line Chart 1: Capital Adequacy

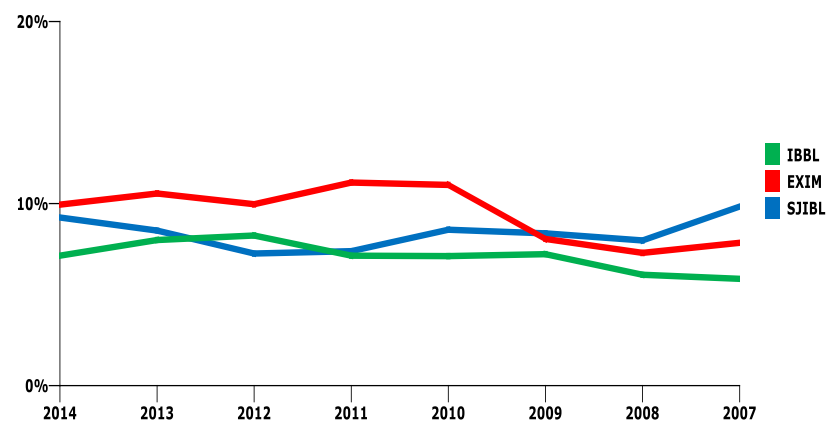

Source: Author's Compilation, 2016

Capital adequacy is measured by using the shareholder's equity to total assets ratio. From the above table and charts, it is found that capital adequacy ratio is well and increasing over the years. The capital adequacy of IBBL was $5.86 \%$ in 2007 which was increased to $7.14 \%$ in 2014 . Besides, EXIM bank capital adequacy increased $7.85 \%$ to 9.94\% and SJIBL capital adequacy little bit decreased which $9.23 \%$ in 2014 and 9.83\% was in 2007 but it is comparatively good position than IBBL and EXIM in 2014.

\section{Asset Quality}

Table 2: Investment Loss Reserves

\begin{tabular}{|l|c|c|c|c|c|c|c|c|}
\hline & $\mathbf{2 0 1 4}$ & $\mathbf{2 0 1 3}$ & $\mathbf{2 0 1 2}$ & $\mathbf{2 0 1 1}$ & $\mathbf{2 0 1 0}$ & $\mathbf{2 0 0 9}$ & $\mathbf{2 0 0 8}$ & $\mathbf{2 0 0 7}$ \\
\hline IBBL & $1.03 \%$ & $0.75 \%$ & $0.94 \%$ & $0.78 \%$ & $0.42 \%$ & $0.59 \%$ & $0.63 \%$ & $0.95 \%$ \\
\hline EXIM & $0.90 \%$ & $1.17 \%$ & $1.39 \%$ & $0.48 \%$ & $0.63 \%$ & $0.55 \%$ & $0.99 \%$ & $0.72 \%$ \\
\hline SJIBL & $1.85 \%$ & $0.36 \%$ & $0.95 \%$ & $0.76 \%$ & $0.93 \%$ & $0.56 \%$ & $0.74 \%$ & $0.48 \%$ \\
\hline
\end{tabular}

Source: Author's Compilation, 2016
Bar Chart 2: Asset Quality

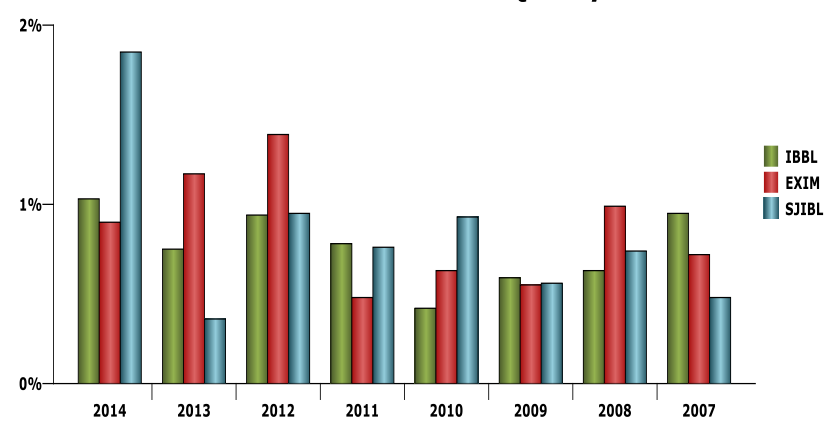

Line Chart 2: Asset Quality

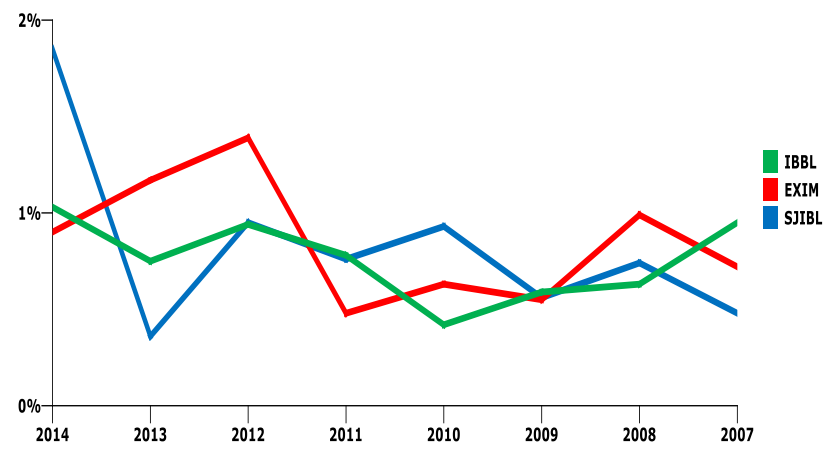

Source: Author's Compilation, 2016

This performance parameter will benefit the bank in understanding the amount of funds that have been reserved by the banks in the event of bad investments. From above table and charts, we have found 3 of these Islamic banks ILR ratios below $2 \%$. This ratio is better to keep as lower as possible. Banks that maintain the high provision for bad investments should be concerned as this will signal towards future losses. So, it is can say less than $2 \%$ indicates good performance.

\section{Management Efficiency}

Table 3: Cost to Income ratio

\begin{tabular}{|l|c|c|c|c|c|c|c|c|}
\hline & $\mathbf{2 0 1 4}$ & $\mathbf{2 0 1 3}$ & $\mathbf{2 0 1 2}$ & $\mathbf{2 0 1 1}$ & $\mathbf{2 0 1 0}$ & $\mathbf{2 0 0 9}$ & $\mathbf{2 0 0 8}$ & $\mathbf{2 0 0 7}$ \\
\hline IBBL & $44.07 \%$ & $43.95 \%$ & $36.23 \%$ & $36.34 \%$ & $38.88 \%$ & $36.88 \%$ & $34.10 \%$ & $37.72 \%$ \\
\hline EXIM & $41.25 \%$ & $39.58 \%$ & $34.03 \%$ & $38.61 \%$ & $23.50 \%$ & $28.35 \%$ & $29.05 \%$ & $32.34 \%$ \\
\hline SJIBL & $53.48 \%$ & $46.46 \%$ & $29.06 \%$ & $35.26 \%$ & $27.26 \%$ & $30.02 \%$ & $22.09 \%$ & $19.27 \%$ \\
\hline
\end{tabular}

Source: Author's Compilation, 2016

\section{Bar Chart 3: Management Efficiency}

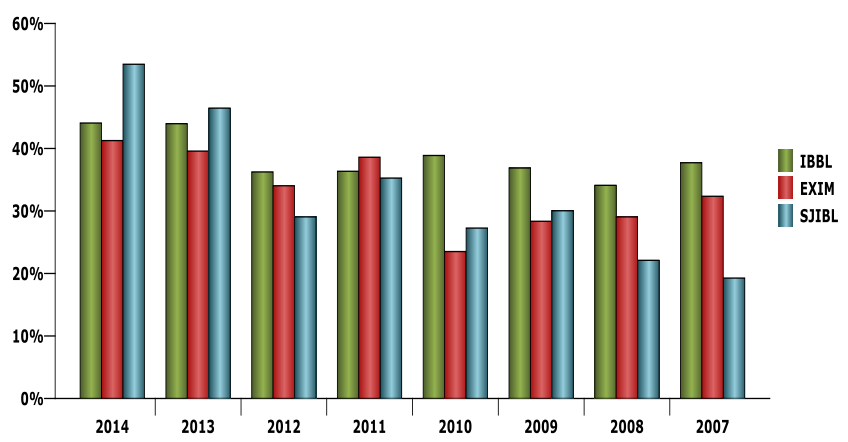




\section{Line Chart 3: Management Efficiency}

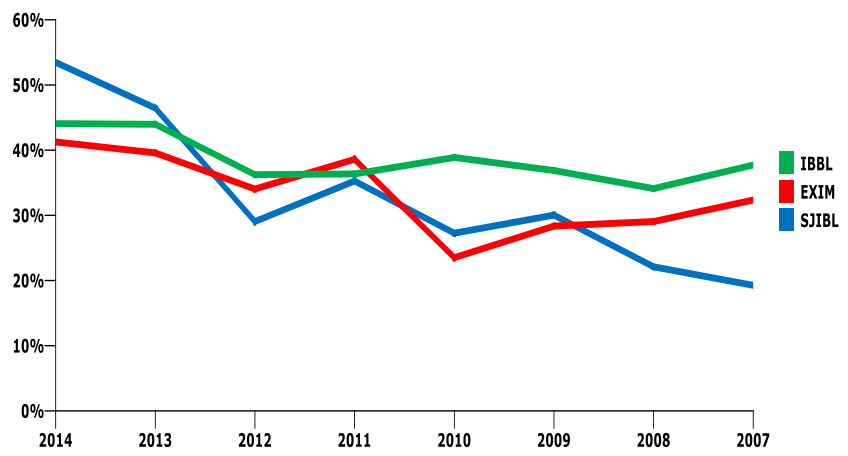

Source: Author's Compilation, 2016

This measure of performance will shed light on the superiority of the management. The duty of the management is to safeguard that the banks operation runs in a smooth and decent manner. Very often, the banks superiority in terms of management is decided by the skill and ability of the management to control the cost and increase productivity, ultimately achieving higher profits. Hence, Total operating expenses to total operating income ratio which is also called cost to income ratio (COSR) utilized to measure the management quality. From the above table and charts, it is found COSR is increasing moderately with slight fluctuation of all 3 banks. In 2007, IBBL COSR was just below $38 \%$ and it increased to just above $44 \%$ in 2014. Besides EXIM bank COSR increased from $32.34 \%$ to $41.25 \%$ and SJIBL COSR was just above $19 \%$ in 2007 and increased to above 53\% in 2014. Comparatively cost is increasing much of SJIBL rather than IBBL and EXIM.

\section{Earning Ability (a)}

Table 4: Return on Assets

\begin{tabular}{|l|c|c|c|c|c|c|c|c|}
\hline & $\mathbf{2 0 1 4}$ & $\mathbf{2 0 1 3}$ & $\mathbf{2 0 1 2}$ & $\mathbf{2 0 1 1}$ & $\mathbf{2 0 1 0}$ & $\mathbf{2 0 0 9}$ & $\mathbf{2 0 0 8}$ & $\mathbf{2 0 0 7}$ \\
\hline IBBL & $0.61 \%$ & $0.90 \%$ & $1.14 \%$ & $1.24 \%$ & $1.35 \%$ & $1.22 \%$ & $1.16 \%$ & $0.75 \%$ \\
\hline EXIM & $1.07 \%$ & $0.98 \%$ & $1.29 \%$ & $1.55 \%$ & $3.07 \%$ & $2.03 \%$ & $1.60 \%$ & $1.81 \%$ \\
\hline SJIBL & $0.59 \%$ & $1.02 \%$ & $1.30 \%$ & $1.09 \%$ & $2.63 \%$ & $1.82 \%$ & $1.81 \%$ & $2.28 \%$ \\
\hline
\end{tabular}

Bar Chart 4: Earning Ability (ROA)

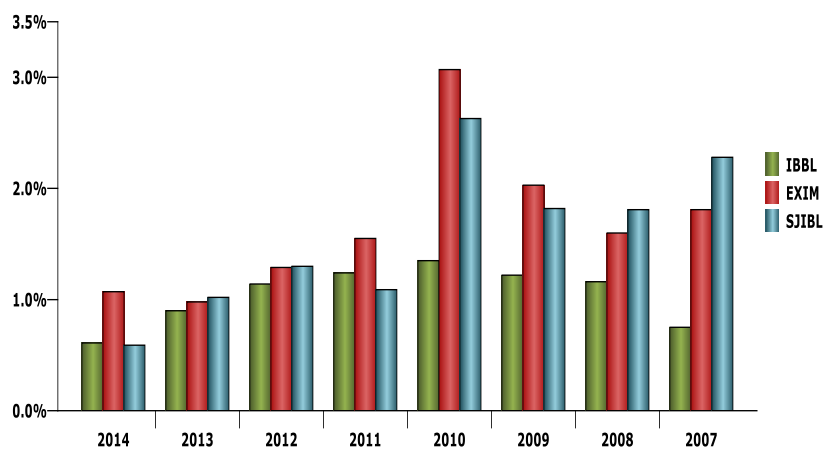

Line Chart 4: Earning Ability (ROA)

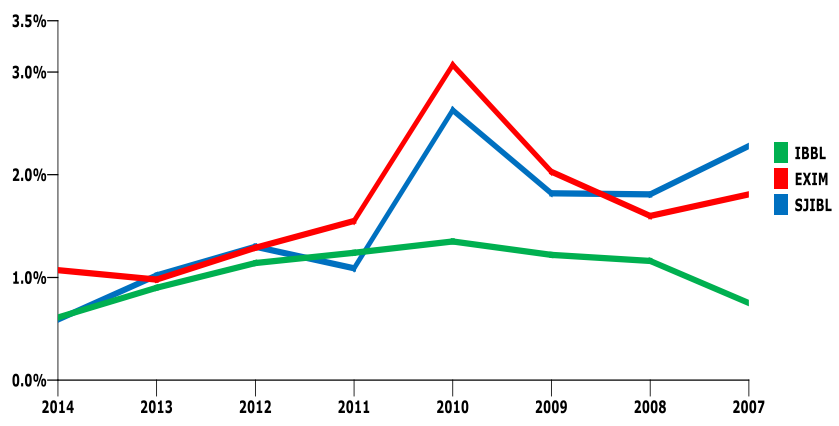

Source: Author's Compilation, 2016

It essentially aids the bank in concentrating on the loss gripping capacity, determining the level of its earnings and revenue as well as the funds available for rewarding its shareholders. This study is employing two performance measures to determine the profitability of the banks. One is Return on Assets (ROA) which is calculated through net profit to total assets. According to above table and charts, the ratio was decreased in 2014 of these three banks. In 2010, IBBL, EXIM, and SJIBL peaked at $1.35 \%, 3.07 \%$, and $2.63 \%$ respectively. But in 2014, IBBL, EXIM and SJIBL return on assets was lowest $0.61 \%, 1.07 \%$, and $1.59 \%$ respectively.

\section{Earning Ability (b)}

Table 5: Return on Equity

\begin{tabular}{|l|c|c|c|c|c|c|c|c|}
\hline & $\mathbf{2 0 1 4}$ & $\mathbf{2 0 1 3}$ & $\mathbf{2 0 1 2}$ & $\mathbf{2 0 1 1}$ & $\mathbf{2 0 1 0}$ & $\mathbf{2 0 0 9}$ & $\mathbf{2 0 0 8}$ & $\mathbf{2 0 0 7}$ \\
\hline IBBL & $8.58 \%$ & $11.31 \%$ & $13.90 \%$ & $17.42 \%$ & $19.00 \%$ & $16.93 \%$ & $19.02 \%$ & $12.72 \%$ \\
\hline EXIM & $10.74 \%$ & $9.28 \%$ & $12.97 \%$ & $13.87 \%$ & $27.86 \%$ & $25.22 \%$ & $21.98 \%$ & $23.03 \%$ \\
\hline SJIBL & $6.39 \%$ & $11.92 \%$ & $17.93 \%$ & $14.76 \%$ & $30.71 \%$ & $21.73 \%$ & $22.68 \%$ & $23.21 \%$ \\
\hline
\end{tabular}

Source: Author's Compilation, 2016

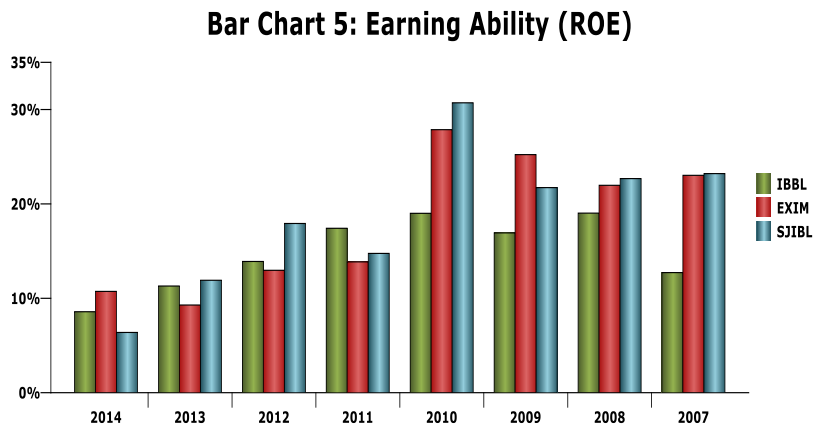

Line Chart 5: Earning Ability (ROE)

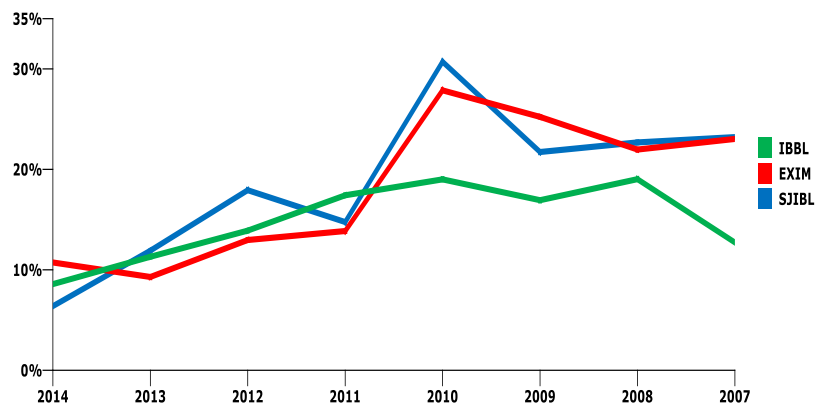

Source: Author's Compilation, 2016 
ROE contributes in understanding the working of the management of the organization on the earnings or income generated from the owner's equity. ROE can be defined to measure the returns on the equity holders to evaluate the growth on their investments. According to above table and charts, ROE is decreasing which is better because lower the ROE indicates better performance of the bank. In 2007, IBBL ROE was just below 13\% and which was decreased to $8.58 \%$ in 2014 . Moreover, EXIM bank ROE decreased $23.03 \%$ to $10.74 \%$ and SJIBL ROE decreased $23.21 \%$ to $6.39 \%$. ROE was at peaked in 2010 of these 3 Islamic banks.

\section{Liquidity}

Table 6: Liquidity (Net Investment to Total Asset)

\begin{tabular}{|c|c|c|c|c|c|c|c|c|}
\hline & $\mathbf{2 0 1 4}$ & $\mathbf{2 0 1 3}$ & $\mathbf{2 0 1 2}$ & $\mathbf{2 0 1 1}$ & $\mathbf{2 0 1 0}$ & $\mathbf{2 0 0 9}$ & $\mathbf{2 0 0 8}$ & $\mathbf{2 0 0 7}$ \\
\hline IBBL & $71.04 \%$ & $73.68 \%$ & $77.28 \%$ & $78.58 \%$ & $79.62 \%$ & $77.12 \%$ & $77.99 \%$ & $75.73 \%$ \\
\hline
\end{tabular}
\begin{tabular}{|l|l|l|l|l|l|l|l|l|}
\hline EXIM & $76.56 \%$ & $73.60 \%$ & $70.77 \%$ & $76.77 \%$ & $82.51 \%$ & $82.34 \%$ & $78.36 \%$ & $78.04 \%$ \\
\hline
\end{tabular} \begin{tabular}{|l|l|l|l|l|l|l|l|l|}
\hline SJIBL & $66.32 \%$ & $66.67 \%$ & $72.42 \%$ & $75.16 \%$ & $77.97 \%$ & $74.61 \%$ & $72.80 \%$ & $72.73 \%$ \\
\hline
\end{tabular} Source: Author's Compilation, 2016

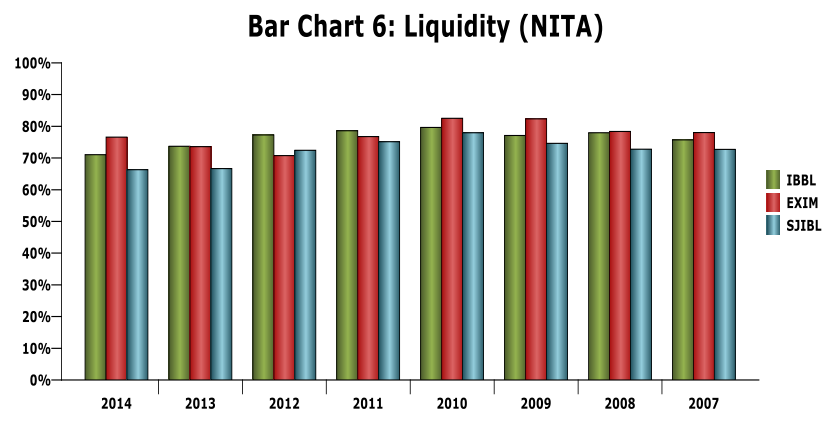

Line Chart 6: Liquidity (NITA)

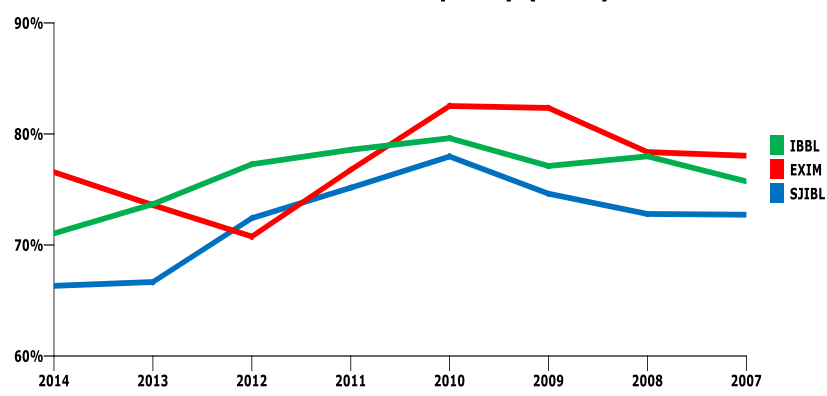

Source: Author's Compilation, 2016

This parameter is for evaluating the risk faced by the banks in case of an unprecedented and unforeseen circumstance that can be the main reason for an insolvency of bank. To assess the liquidity of the banks, the researcher has used the net investment to total assets (NITA). From the above table and charts, it is found that net investment was more than $65 \%$ of total assets of these selected Islamic banks. In 2014, IBBL NITA was just above $70 \%$ which was lower than rest of 7 years. EXIM bank NITA was above $76 \%$ in 2014 and SJIBL was looked better $66.32 \%$ in 2014 . The only reason being, that high NITA indicates that the bank is engaged highly in lending, and this may have adverse effects as the bank might face the huge risk of defaulters.

\section{Composite Rating}

Table 7: Composite Rating of Islami Bank Bangladesh Limited (IBBL)

\begin{tabular}{|c|c|c|c|c|c|c|c|c|}
\hline & $\mathbf{2 0 1 4}$ & $\mathbf{2 0 1 3}$ & $\mathbf{2 0 1 2}$ & $\mathbf{2 0 1 1}$ & $\mathbf{2 0 1 0}$ & $\mathbf{2 0 0 9}$ & $\mathbf{2 0 0 8}$ & $\mathbf{2 0 0 7}$ \\
\hline Rating & 1 & 1 & 1 & 1 & 1 & 1 & 1 & 1 \\
\hline $\begin{array}{c}\text { Composite } \\
\text { Value }\end{array}$ & 1.32 & 1.39 & 1.38 & 1.42 & 1.46 & 1.40 & 1.39 & 1.34 \\
\hline
\end{tabular}

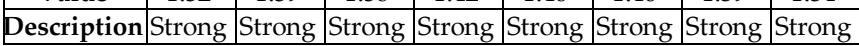

Source: Author's Compilation, 2016

Table 8: Composite Rating of EXIM Bank Limited

\begin{tabular}{|c|c|c|c|c|c|c|c|c|}
\hline & $\mathbf{2 0 1 4}$ & $\mathbf{2 0 1 3}$ & $\mathbf{2 0 1 2}$ & $\mathbf{2 0 1 1}$ & $\mathbf{2 0 1 0}$ & $\mathbf{2 0 0 9}$ & $\mathbf{2 0 0 8}$ & $\mathbf{2 0 0 7}$ \\
\hline Rating & 1 & 1 & 1 & 1 & 1 & 1 & 1 & 1 \\
\hline $\begin{array}{c}\text { Composite } \\
\text { Value }\end{array}$ & 1.40 & 1.35 & 1.30 & 1.42 & 1.49 & 1.47 & 1.39 & 1.44 \\
\hline
\end{tabular}

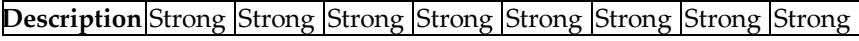

Source: Author's Compilation, 2016

Table 9: Composite Rating of Shahjalal Islami Bank Limited (SJIBL)

\begin{tabular}{|c|c|c|c|c|c|c|c|c|}
\hline & $\mathbf{2 0 1 4}$ & $\mathbf{2 0 1 3}$ & $\mathbf{2 0 1 2}$ & $\mathbf{2 0 1 1}$ & $\mathbf{2 0 1 0}$ & $\mathbf{2 0 0 9}$ & $\mathbf{2 0 0 8}$ & $\mathbf{2 0 0 7}$ \\
\hline Rating & 1 & 1 & 1 & 1 & 1 & 1 & 1 & 1 \\
\hline $\begin{array}{c}\text { Composite } \\
\text { Value }\end{array}$ & 1.38 & 1.35 & 1.29 & 1.34 & 1.48 & 1.37 & 1.28 & 1.28 \\
\hline
\end{tabular}

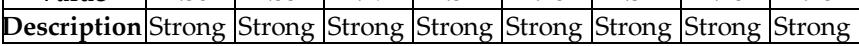

Source: Author's Compilation, 2016

Bar Chart 7: Composite Ratings

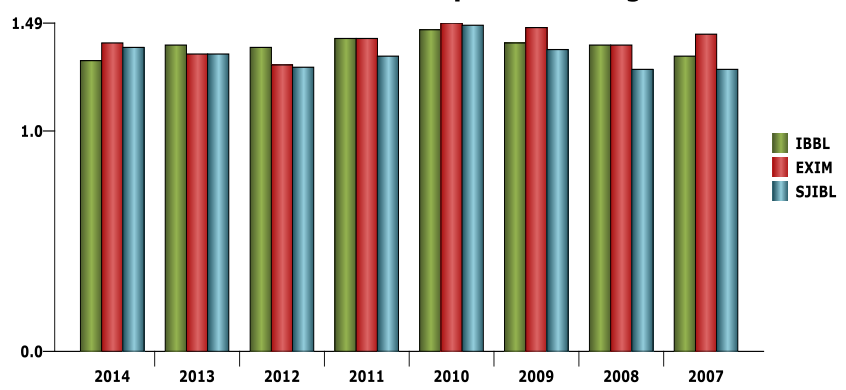

Source: Author's Compilation, 2016

Khan (2008) stated that there are five categories of the composite ratings. Among these, rating 1 which range is 1.00 to 1.49 that indicates bank performance is 'Strong'. According to above tables and chart, it is found 3 of these banks' composite range was between 1.00 to 1.49 through the period of 2007 to 2014 . That's means; the performance of selected Islamic banks is strong under this study. These selected Islamic banks are sound in every respect.

\section{Conclusion}

To uplift the economy of the country, financial sector is required to be developed. In this connection, the banking sector must be given priority to attain sustainability in financial sector. So, the smooth and efficient operation of banking sector helps to reduce the risk of failure of an economy. Therefore, the performance of banking sector has always been a source of interest for researchers to judge the economic condition of a country. Regulators of the banking sector always monitors the performance of the banks to ensure efficient financial system based on CAMEL model. 
This study has been conducted to examine financial performance of three selected Islamic banks among eight Islamic banks in Bangladesh during 2007-2014. This study is based on measuring performance of banks with respect to CAMEL model and shows that all selected Islamic banks' (IBBL, EXIM bank, and SJIBL) financial performance under CAMEL rating is 'strong' in every respect.

Performance is a continuous process, and it requires continuous innovation and improvement to adjust with the increasing demand. So, the trend of the performance of Islamic banking sector in Bangladesh can be improved more if all concerns pay due attention and work according to the requirement of time.

\section{REFERENCES}

Akkas, A. (1996). Relative Efficiency of the Conventional and Islamic Banking System in Financing Investment. PhD Dissertation, Dhaka University.

Barker, D., \& Holdsworth, D.(1993). The Causes of Bank Failures in the 1980s. Research Paper No. 9325, Federal Reserve Bank of New York.

Barr, R. S., Killgo, K. A., Siems, T. F., and Zimmel, S. (2002).Evaluating the Productive Efficiency and Performance of U.S. Commercial Banks. Engineering Management, 28(8), p. 19.

Cole, R. A., \& Gunther, J. (1998).Predicting Bank Failures: A Comparison of On-And Off-Site Monitoring Systems. Journal of Financial Services Research, 13(2), pp. 103-117.

Dar, H. A., \& Presley, J. R. (2000). Lack of profit loss sharing in Islamic banking: Management and Control Imbalances. International Journal of Islamic Financial Services, 2(2), 3-18.

Deyoung, R., Flannery, M.J., Lang, W.W.,\& Sorescu, S.M. (2001). The Information Content of Bank Exam Ratings and Subordinated Debt Prices. Journal of Money, Credit and Banking, Vol. 33, No. 4, p.900-925.

Doumpos, M., \& Zopounidis,C. (2009). A Multicriteria Bank Rating System. European Working Group "Multiple Criteria Decision Aiding", Spring, Series 3, No 19, p.17-19.

Godlewski, C. (2003). Bank's Default Modelisation: An Application to Banks from Emerging Market Economies. Journal of Social Science Research Network, Vol.4, No.3, pp. 150-155.

Gupta, M., \& Siabal, S.K. (2007), Profitability and Productivity in Banks a Comparative Study, Journal of Business Management, Vol.1, No.2, pp.137-152.

Hazzi, O.A. \& Kilani, M.I.A. (2013). The Financial Performance Analysis of Islamic and Traditional Banks: Evidence from Malaysia. European Journal of Economics, Finance and Administrative Sciences, Issue:57, February 2013, ISSN: 14502275

Iqbal, M. J., (2012). Banking Sector's Performance In Bangladesh An Application Of Selected Camels Ratio, Asian Institute of Technology, School of Management, Thailand, Retrieved: 10 January 2016, from http:/ / www.bankingandfinance.ait.asia/sites/default/files/r eport/report_jahidiqbal.pdf

Islami Bank Bangladesh Limited, Annual Report. (2007-2014). Retrieved Jan. 5, 2016, from http://www.islamibankbd.com/annual_report.php

Jaffar, M., \& Manarvi, I. (2011). Performance Comparison of Islamic and Conventional Banks in Pakistan. Global Journal of Management and Business Research, 11(1), 59-66.
Kabir, M. A., \& Dey, S. (2012) Performance Analysis through CAMEL Rating: A Comparative Study of Selected Private Commercial Banks in Bangladesh. Journal of Politics $\mathcal{E}$ Governance, Vol. 1, No. 2/3, September 2012, pp. 16-25.

Kader, J. M., Asarpota, A. J., \& Al-Maghaireh, A. (2007). Comparative Financial Performance of Islamic Banks vis-à-vis Conventional Banks in the UAE. Proceeding on Annual Student Research Symposium and the Chancellor's Undergraduate Research Award.

Khan, A. R. (2008). Bank Management- A Fund Emphasis. First edition, $2^{\text {nd }}$ Print, P-59-60, Ruby publications, Dhaka.

Merchant, I. P. (2012). Performance analysis of banks using CAMEL approach, An Empirical study of Islamic Banks Versus Conventional Banks of GCC.

Najjar, O. K. (2008). Financial Analysis for Bank of Palestine \& Jordan Ahli Bank (CAMEL Analysis). Social Science Research Network, [online] Retrieved: 06 January 2016, from http://ssrn.com/abstract $=1329588$

Nimalathasan, B. (2008). A Comparative Study of Financial Performance of Banking Sector in Bangladesh - An Application of CAMELS Rating System", Annals of University of Bucharest, Economic and Administrative series, nr. 2 (2008), 141-152.

Nurazi, R., \& Evans, M. (2005). 'An Indonesian Study of the Use of CAMEL Ratios as Predictors of Bank Failure', Journal of Economic and Social Policy, vol. 10, no. 1, pp. 1-23.

Patrick Y. Trautmann. (2006). "USAID-Funded Economic Governance II Project", p.45-49.

Piyu, Y. (1992). Data Envelopment Analysis \& Commercial Bank Performance: A Primer with Application to Missouri Banks. Austin: IC2 Institute, University of Texas.

Rosly, S. A., \& Bakar, M. A. A. (2003). Performance of Islamic and Mainstream Banks in Malaysia. International Journal of Social Economics, 30 (12), 1249-1265.

Said, M., \& Saucier, P. (2003). Liquidity, Solvency, and Efficiency: An Empirical Analysis of the Japanese Bank's Distress. University of Birmingham 20th Symposium on Banking and Monetary Economics

Saifullah, M. (2010). Superiority of Conventional Banks \& Islamic Banks of Bangladesh:. International Journal of Economics and Finance Vol.2, No.3, August 2010.

Samad, A. (1999). Comparative Efficiency of the Islamic Bank Malaysia vis-à-vis Conventional Banks. IIUM Journal of Economics and Management, 7 (1), 1-25.

Samad, A., \& Hassan, M. K. (2000). The performance of Malaysian Islamic Bank During 1984 -1997: An Explanatory Study. Thoughts on Economics, 10 (1\&2), 7-26.

Samad, A. (2004). Performance of Interest Free Islamic Banks vis-àvis Interest-Based Conventional Banks of Bahrain. IIUM Journal of Economics and Management, 12 (2), 1-25.

Sarker, M. A. A. (1999). Islamic Banking in Bangladesh: Performance, Problems and Prospects. International Journal of Islamic Financial Services. (Oct-Des), 1 (3).

Sarker, M. A. A. (2005).CAMEL Rating System in the Context of Islamic Banking: A Proposed ' $\mathrm{S}$ ' for Shariah Framework. Journal of Islamic Economics and Finance, vol. 1, no.1, pp. 78-84.

Shahjalal Islami Bank Limited, Annual Report (2007-2014). Retrieved Jan. 5, 2016, from http://www.sjiblbd.com/Financial_Statements_2014.php

Siems, T. F., \& Barr, R. S. (1998). Benchmarking the Productive Efficiency of U.S. Banks: Financial Industry Studies. Federal Reserve Bank of Dallas.

Tarawneh, M. (2006). A Comparison of Financial Performance in the Banking Sector: Some Evidence from Omani Commercial 
Banks. International Research Journal of Finance and Economics, Issue (3). ISSN 1450-2887

Verma, M. S. (2003), "Report of the Working Group on Restructuring Weak Public Sector Banks", RBI Publications.

Vong, A., \& Chan, H. (2009) “Determinants of Bank Profitability in Macau", Macau Monetary Research Bulletin, 12, pp. 93-113

Wibowo, E., \& Saptutyningsih, E. 2004. Analysis of Performance of Bank Muamalat Indonesia and Bank Syariah Mandiri. Journal of Economic Study, 5 (1), 20-25.

Widagdo, A. K., \& Ika, S. R. (2007). The Interest Prohibition and Financial Performance of Islamic Banks: Indonesia Evidence.
Paper presented in 19th Asian-pacificConference on International Accounting Issues. November 11-14, Kuala Lumpur, Malaysia.

Wirnkar, A. D., \& Tanko, M. (2008), CAMELS and Banks Performance Evaluation: The Way Forward. Working Paper Series. Social Science Research Network. Retrieved Jan. 15, 2015, from http:/ / ssrn.com/abstract=11

EXIM Bank Limited, Annual Report (2007-2014). Retrieved Jan. 5, 2016, from http:/ / www.eximbankbd.com

Bangladesh Bank Annual Report. (2014). Retrieved Jan. 15, 2016, from http://www.bb.org.bd

$$
\text { -- } 0 \text {-- }
$$


Publish Online and Print Version Both

Online ISSN: 2305-8730

Online Archive: http://journals.abc.us.org/index.php/abr/issue/archive

Indexed Archive Links

OCLC WorldCat: http://goo.gl/vhQzla

Google Scholar: https://goo.gl/t23FeQ abcGATE: http://goo.g1/E6WdgA

BASE: $\underline{\mathrm{http}: / / g o o . g 1 / \mathrm{sEd} 0 \mathrm{SZ}}$

\section{5.) WorldCat}

\section{Google scholar}

